\title{
Nitrile hydrolysis by Rhodococcus erythropolis BL1, an acetonitrile-tolerant strain isolated from a marine sediment
}

\author{
Bjarne R. Langdahl, Peter Bisp and Kjeld Ingvorsen
}

Department of Microbial Ecology, Institute of Biological Science, $\mathrm{Ny}$ Munkegade, Bldg 540, University of Aarhus, DK8000 Aarhus C, Denmark
Author for correspondence: Kjeld Ingvorsen. Tel: +45 89423245. Fax: +4586127191. e-mail: Kjeld@pop.bio.aau.dk

A number of physiologically different nitrile-hydrolysing bacteria were isolated from coastal marine sediments in Denmark by enrichment culture. One strain, BL1, identified as Rhodococcus erythropolis, grew on acetonitrile as sole carbon and nitrogen source in a defined medium. Growth occurred between 0 and $8 \% \mathrm{NaCl}$ with an optimum around $2 \%$, thus reflecting the marine origin of the isolate. Intact cells of $R$. erythropolis BL1 could hydrolyse a large variety of saturated and unsaturated aliphatic nitriles to their corresponding acids. Benzonitrile and benzylcyanide were not hydrolysed, whereas some aromatic compounds containing a $-\mathrm{CN}$ group attached to a $\mathrm{C}_{3}$ or $\mathrm{C}_{4}$ aliphatic side chain were accepted as substrates. The substrate spectrum of $R$. erythropolis BL1 was thus markedly different from those of other Grampositive nitrile-hydrolysing bacteria isolated from non-marine environments. Nitrile hydrolysis during growth and in resting cell suspensions usually occurred without intermediate accumulation of amide outside the cells. Detailed studies, however, showed that nitrile hydrolysis by strain BL1 was due to a nitrile hydratase/amidase enzyme system. Nitrile hydratase activity was found to be inducible whereas amidase activity was constitutive. The amidase activity of cells could, however, be enhanced manyfold by growth in media containing acetamide or acetonitrile. In most cases amides were hydrolysed at a much higher rate than the corresponding nitriles, which explained why amides were rarely detected in the surrounding medium during nitrile hydrolysis. $R$. erythropolis BL1 exhibited the highest tolerance towards acetonitrile ever reported for a nitrile-hydrolysing bacterium, as demonstrated by its ability to grow exponentially in the presence of $900 \mathrm{mM}$ acetonitrile.

Keywords: Rhodococcus erytbropolis, nitrile hydratase, amidase, marine sediments, substrate tolerance

\section{INTRODUCTION}

Several micro-organisms have been reported to hydrolyse both aliphatic and aromatic nitriles (DiGeronimo \& Antoine, 1976; Harper, 1977; Jallageas et al., 1980; Asano et al., 1982; Ingvorsen et al., 1988; Nawaz et al., 1992). In bacteria, hydration of nitriles proceeds by two different enzymic pathways: (1) a hydratase/amidase enzyme system which catalyses the reaction to the corresponding carboxylic acid and ammonia in a two-step reaction via a free amide intermediate, or (2) a nitrilase enzyme which catalyses the reaction in one step. In addition to these

Abbreviations: AHA, amide-hydrolysing activity; NHA, nitrile-hydrolysing activity. hydration reactions, reduction of nitriles by nitrogenase enzymes has been described (Jallageas et al., 1980; Finnegan et al., 1992).

Many naturally occurring nitriles have been described (Jallageas et al., 1980; Vennesland et al., 1981). However, only a few (e.g. ricinine and mandelonitrile) have been reported to be hydrolysed by bacteria (Robinson \& Hook, 1964; Yamamoto et al., 1991). Indeed, most nitrilehydrolysing bacteria described in detail have been enriched and finally isolated using media containing synthetic nitriles as carbon and/or nitrogen sources.

Many synthetic nitrile compounds are used in industrial operations (Wyatt \& Linton, 1988). The widespread usage of nitriles has created considerable commercial 
interest in nitrile-hydrating enzymes, both as biocatalysts for chemical syntheses (Nagasawa \& Yamada, 1989) and as a means of biological detoxification of nitrile-containing waste (Knowles \& Wyatt, 1992; Chapatwala et al., 1993). Industrial usage of nitriles may result in discharge of synthetic nitriles into marine, freshwater and soil environments, where they may be detoxified by natural populations of nitrile-hydrolysing micro-organisms. All nitrile-hydrolysing bacteria described in the literature appear to have been isolated from soils or freshwater environments (DiGeronimo \& Antoine, 1976; Harper, 1977; Jallageas et al., 1980). The present study was initiated with the aim of gaining information about nitrilehydrolysing bacteria in marine sediments. We report here the isolation and characterization of a marine strain capable of hydrolysing organic nitriles.

\section{METHODS}

Composition of media. The defined basal medium (DE medium) used for enrichment and isolation of acetonitrileutilizing micro-organisms contained the following components (g per litre Milli-Q Plus water): $\mathrm{NaCl}, 20 ; \mathrm{MgCl}_{2} \cdot 6 \mathrm{H}_{2} \mathrm{O}, 3$; $\mathrm{KCl}, 0.5 ; \mathrm{MgSO}_{4} .7 \mathrm{H}_{2} \mathrm{O}, 0.3 ; \mathrm{CaCl}_{2} .2 \mathrm{H}_{2} \mathrm{O}, 0.15 ; \mathrm{K}_{2} \mathrm{HPO}_{4}$, $1.03 ; \mathrm{KH}_{2} \mathrm{PO}_{4}, 0.75$; and $1 \mathrm{ml}$ each of the following three solutions: trace element solution (TES-3), vitamin mixture (VM) and vitamin $\mathrm{B}_{12}$ solution. TES-3 contained (in $\mathrm{mg}$ per litre Milli-Q Plus water): $\mathrm{FeCl}_{2} \cdot 4 \mathrm{H}_{2} \mathrm{O}, 2000 ; \mathrm{CoCl}_{2} \cdot 6 \mathrm{H}_{2} \mathrm{O}$, $250 ; \quad \mathrm{MnCl}_{2} .4 \mathrm{H}_{2} \mathrm{O}, 100 ; \mathrm{ZnCl}_{2}, 70 ; \mathrm{H}_{3} \mathrm{BO}_{3}, \quad 6$; $\mathrm{Na}_{2} \mathrm{MoO}_{4} \cdot 2 \mathrm{H}_{2} \mathrm{O}, 40 ; \mathrm{NiCl}_{2} \cdot 6 \mathrm{H}_{2} \mathrm{O}, 70 ; \mathrm{CuCl}_{2} \cdot 2 \mathrm{H}_{2} \mathrm{O}, 2$; $\mathrm{AlCl}_{3} .6 \mathrm{H}_{2} \mathrm{O}, 60 ; \mathrm{NaWO}_{4} \cdot 2 \mathrm{H}_{2} \mathrm{O}, 6$. The $\mathrm{VM}$ contained the following seven vitamins (in $\mathrm{mg}$ per litre $25 \mathrm{mM}$ sodium phosphate buffer, $\mathrm{pH} 7 \cdot 0)$ : pyridoxamine dihydrochloride, 100 ; calcium $\mathrm{D}(+)$-pantothenate, 50 ; nicotinic acid, 100 ; DL- $\alpha$-lipoic acid, 10; folic acid, 30; D- $(+)$-biotin, 10; 4-aminobenzoic acid, 40. The vitamin $B_{12}$ solution contained $50 \mathrm{mg}$ cyanocobalamin per litre Milli- $\mathrm{Q}$ Plus water. The $\mathrm{pH}$ of the $\mathrm{DE}$ medium was adjusted to $7 \cdot 2$ with $\mathrm{NaOH}$ or $\mathrm{H}_{3} \mathrm{PO}_{4}$ before autoclaving. After heat sterilization $\left(121^{\circ} \mathrm{C}, 20 \mathrm{~min}\right)$ and cooling, one $\mathrm{ml}$ of a $0 \cdot 2 \mu \mathrm{m}$ filter-sterilized solution of thiamin hydrochloride (100 $\mathrm{mg}$ per litre $10 \mathrm{mM}$ sodium phosphate buffer, $\mathrm{pH} \mathrm{3.4)}$ was added to the medium. Solid DE medium contained $15 \mathrm{~g}$ Bacto agar (Difco) $1^{-1}$. Agar plates of complex medium (CM) were used for testing the purity of nitrile-hydrolysing isolates. CM had the following composition (in g per litre DE medium): beef extract, 8; yeast extract, 1; Bacto agar, 15. Unless otherwise stated, all media, substrates and reagent solutions were prepared in Milli-Q Plus water.

Enrichment and isolation of bacteria. Samples of marine sediment were collected from different localities on the east and west coasts of Denmark. Enrichments were initiated by adding $1 \mathrm{ml}$ sediment sample to $100 \mathrm{ml} \mathrm{DE}$ medium in $500 \mathrm{ml}$ Erlenmeyer flasks with aluminium caps used for aerobic cultivation of micro-organisms (hereinafter referred to as 'experimental flasks'). Finally acetonitrile, serving as the sole carbon and nitrogen source, was added aseptically to the experimental flasks to a final volumetric concentration of $0.5 \%$ (95 mM) (hereafter referred to as DE/acetonitrile medium). Enrichment flasks were incubated aerobically at $23{ }^{\circ} \mathrm{C}$ on a gyrotory incubator (Innova, model 4000, New Brunswick Scientific) at 180 r.p.m., and checked daily for production of ammonia (as an indication of nitrile hydrolysis). If positive, $1 \mathrm{ml}$ of the culture was transferred to a new experimental flask with $\mathrm{DE} /$ acetonitrile medium. After several transfers, cultures still showing ammonia production were diluted serially in DE medium and plated on DE/acetonitrile agar medium. Wellseparated colonies were picked and transferred to liquid DE medium and checked for nitrile-hydrolysing activity as described below. Nitrile-hydrolysing isolates were finally checked for purity by plating on nitrile-free CM. Unless otherwise stated, isolates were maintained and grown in $100 \mathrm{ml} \mathrm{DE} /$ acetonitrile medium at $23^{\circ} \mathrm{C}$ on a gyrotory incubator at 180 r.p.m.

Identification of micro-organisms. Initial identifications of the isolates were carried out according to Goodfellow \& Lechevalier (1989) and Goodfellow (1989). The biochemical tests and staining procedures were performed as described by Doetsch $e t$ al. (1981). Final identification of strain BL1 described in the present study, by chemotaxonomy and 16S rRNA analysis was done by DSM (Deutsche Sammlung von Mikroorganismen und Zellkulturen GmbH, Braunschweig, Germany).

Preparation of washed cells. Cells grown to mid-exponential phase in DE/acetonitrile medium $\left(\mathrm{OD}_{600} \sim 2-3\right.$ ) were harvested by centrifugation at $6500 \mathrm{~g}$ in a Sorvall centrifuge (model $\mathrm{RC}-5$, Dupont Instruments) for $10 \mathrm{~min}$ at $10^{\circ} \mathrm{C}$. The cells were washed twice in $100 \mathrm{mM}$ phosphate buffer ( $\mathrm{pH} 7 \cdot 0$ ) and resuspended in phosphate buffer. The washed cell suspension was used immediately or stored overnight at $4{ }^{\circ} \mathrm{C}$.

To avoid carry-over of medium components, growth experiments were initiated by using an inoculum of washed cells prepared as described above, but under aseptic conditions (aseptically washed cells).

Salt range for growth. To study the effect of $\mathrm{NaCl}$ on growth, eight experimental flasks were prepared with $\mathrm{DE}$ medium containing the following additions of $\mathrm{NaCl}: 0,1,2,3,4,5,6$ and $8 \%(\mathrm{w} / \mathrm{v})$. The flasks were inoculated with a suspension of aseptically washed cells (pregrown at $2 \% \mathrm{NaCl}$ ) to an initial $\mathrm{OD}_{600}$ of $\sim 0.2$. Acetonitrile $(0.5 \%, \mathrm{v} / \mathrm{v})$ was added as sole carbon and nitogen source. Incubation was carried out under the conditions described above, and growth was evaluated by measuring $\mathrm{OD}_{600}$ after $120 \mathrm{~h}$ incubation.

Growth at different concentrations of acetonitrile. To investigate the kinetics of growth at different concentrations of acetonitrile, DE medium was supplemented with $30,50,300$, 500 or $1000 \mathrm{mM}$ acetonitrile as sole carbon and nitrogen source. The experimental flasks were inoculated with a suspension of aseptically washed cells to an initial $\mathrm{OD}_{600}$ of approximately $0 \cdot 2$, and incubated under the conditions described above. At intervals samples $(2 \mathrm{ml})$ were aseptically removed from the cultures for measurement of $\mathrm{OD}_{600}$ and $\mathrm{pH}$. Afterwards the samples were centrifuged and the cell-free supernatant withdrawn and stored at $-20{ }^{\circ} \mathrm{C}$ until analysed for metabolites as described below.

Nitriles and amides as growth substrates. A number of nitriles and amides were tested for their ability to serve as sole carbon and nitrogen source for growth of strain BL1. Potential substrates were added to experimental flasks, which were inoculated with a suspension of aseptically washed cells pregrown in DE/acetonitrile medium. Liquid substrates were added to a final concentration of $0.3 \%(\mathrm{v} / \mathrm{v})$ and solid substrates to a final concentration of $30 \mathrm{mM}$. Growth was evaluated as $\mathrm{OD}_{600}$ after $72 \mathrm{~h}$ incubation.

Assay for enzyme activities. Nitrile-hydrolysing activity (NHA) and amide-hydrolysing activity (AHA) were assayed by measuring the ammonia released from the nitrile and amide substrates, respectively, in reaction mixtures containing washed cells.

The amidase activity of strain BL1 was found to be substantially higher than the nitrile hydratase activity for most substrates. 
Therefore, measurement of ammonia release from nitriles is a quantitative measurement of NHA in most instances. The reaction mixture contained $2 \mathrm{ml}$ washed cells (diluted to a final $\mathrm{OD}_{600}$ of 1-2) in $100 \mathrm{mM}$ phosphate buffer ( $\mathrm{pH} \mathrm{7.0)}$. The reaction was started by addition of the substrate to a final concentration of $30 \mathrm{mM}$. Incubation was at $30{ }^{\circ} \mathrm{C}$ in an Eppendorf thermomixer (model 5437). Samples $(0.2 \mathrm{ml})$ of the reaction mixture were removed at $20 \mathrm{~min}$ intervals for $60 \mathrm{~min}$ and centrifuged for $5 \mathrm{~min}$ at $3500 \mathrm{~g}$ in a Sigma centrifuge (model 113). The cell-free supernatant was either analysed immediately for ammonia or stored $\left(-20^{\circ} \mathrm{C}\right)$ for subsequent analysis. Two types of controls were performed for each substrate tested to correct for ammonia released from cells and chemical hydration of substrates, respectively (Miller \& Gray, 1982; Ingvorsen et al., 1991). One unit of enzyme activity is defined as the amount of enzyme which produces $1 \mu \mathrm{mol} \mathrm{NH}_{4}^{+} \min ^{-1}$ under the conditions stated above.

Substrate specificity. The NHA and AHA assay procedures were used to test the enzyme specificities of washed cells of strain BL1 precultivated in DE/acetonitrile medium $(0.5 \%$, $\mathrm{v} / \mathrm{v}$ ) towards a wide range of nitriles and amides (see Table 1 ). In each case the concentration of substrate in the reaction mixture was $30 \mathrm{mM}$. Methanol $(5 \%, \mathrm{v} / \mathrm{v})$ was added to the reaction mixture to enhance the solubility of hydrophobic substrates. Control experiments with hydrophilic substrates showed that reaction rates were not affected by methanol.

Induction of NHA and AHA. The effects of various nitrogen compounds on NHA and AHA were tested after precultivation of strain BL1 for many generations in $\mathrm{DE} /$ acetonitrile medium $(0.5 \%, \mathrm{v} / \mathrm{v})$ or DE/glucose/ammonia medium $(40 \mathrm{mM} / 15 \mathrm{mM})$, respectively. Cells precultivated in these two media (referred to as induced and non-induced cells, respectively) were harvested in the exponential growth phase, washed aseptically, and used to inoculate experimental flasks with DE medium supplemented with various carbon and nitrogen sources: acetonitrile $(0.5 \%, \mathrm{v} / \mathrm{v})$, acetonitrile/glucose $(0.5 \%$ / $40 \mathrm{mM})$, acetonitrile/glucose/ammonia $(0.5 \% / 40 \mathrm{mM} /$ $15 \mathrm{mM})$, glucose/ammonia $(40 \mathrm{mM} / 15 \mathrm{mM})$, acetamide $(50 \mathrm{mM})$, acetamide/glucose $(50 \mathrm{mM} / 40 \mathrm{mM})$ and benzonitrile $(20 \mathrm{mM})$. After 24 and $48 \mathrm{~h}$ growth in these test media, samples were withdrawn from each flask and assayed for NHA as described above. Some cultures were also assayed for amidase activity (AHA) after 24 h growth.

Analytical methods. Samples of cell suspensions from growth and activity experiments were withdrawn at intervals and the cells removed by centrifugation in a Sigma (model 113) centrifuge ( $5 \mathrm{~min}$ at $3500 \mathrm{~g}$ ). The clear supernatant was removed and used for analyses of acetonitrile, acetamide, acetate and ammonia as described below. Acetonitrile and acetamide were determined by gas chromatography using a Chrompack model 438 A gas chromatograph equipped with a flame ionization detector connected to a Shimadzu CR 601 Chromatopack integrator. A stainless steel column $(2 \mathrm{~m} \times 2.4 \mathrm{~mm}$ i.d.) packed with Porapak Q (mesh 80-100) was used as analytical column. For acetonitrile the column, injector and detector temperatures were set at 175,210 and $250^{\circ} \mathrm{C}$, respectively. For acetamide the temperatures were changed to 225,250 and $300^{\circ} \mathrm{C}$, respectively. Nitrogen was used as carrier gas at a flow rate of $30 \mathrm{ml} \mathrm{min}^{-1}$.

Acetate was analysed by reverse-phase chromatography using a Sykam high-performance liquid chromatograph (HPLC) system consisting of a pump (model S 1100), a column oven (model S 4110), a UV-detector (model LDS 3200) and an autosampler (Jasco, model 851-AS). The analytical column $(300 \mathrm{~mm} \times 7.8 \mathrm{~mm}$; Aminex HPX-87H, Bio-Rad) was held at $60^{\circ} \mathrm{C}$. Elution was isocratic at a flow rate of $0.9 \mathrm{ml} \mathrm{min}^{-1}$ using
$0.025 \mathrm{M} \mathrm{H}_{2} \mathrm{SO}_{4}$ as mobile phase. The absorbance was measured at $218 \mathrm{~nm}$.

Ammonia was analysed by the salicylate/hypochlorite method according to Bower \& Holm-Hansen (1980) using a Hitachi spectrophotometer (model U-2000).

Bacterial growth was followed by measurements of $\mathrm{OD}_{600}$ with a Bausch and Lomb spectrophotometer (Spectronic 70). Samples were removed aseptically from the culture and if necessary diluted with Milli-Q Plus water to $\mathrm{OD}_{600}$ values less than 1.0 prior to measurements.

Bacterial dry weight was determined by drying samples $(2-10 \mathrm{ml})$ of culture broth previously washed with Milli-Q Plus water at $105^{\circ} \mathrm{C}$ for $24 \mathrm{~h}$. Protein was determined according to the procedure of Goa (1953) using BSA (Sigma) as standard. Calibration curves were constructed to relate $\mathrm{OD}_{600}$ to dry weight $\left(\mathrm{mg} \mathrm{l}^{-1}\right)$ and protein $\left(\mathrm{mg} \mathrm{l}^{-1}\right)$. One unit of $\mathrm{OD}_{600}$ corresponded to $615 \mathrm{mg} \mathrm{dry} \mathrm{weight} \mathrm{l}^{-1}$ or $313 \mathrm{mg}$ protein $\mathrm{l}^{-1}$.

Chemicals. All chemicals were of analytical-grade quality and purchased from commercial suppliers.

Replication of experiments. Growth experiments were done in duplicate; activity assays were done in triplicate and plotted as mean values.

\section{RESULTS}

\section{Isolation of nitrile-hydrolysing bacteria and identification of isolate BL1}

Five different nitrile-hydrolysing species were isolated from marine sediments sampled on the east and west coast of Denmark. A Gram-positive strain, designated BL1, obtained from Aarhus Bight sediment by repeated plating on $\mathrm{DE} /$ acetonitrile agar medium, was chosen for further studies due to its high NHA. The colonies of strain BL1 on DE/acetonitrile agar medium were $3-5 \mathrm{~mm}$ in diameter (4-6 d old), circular, convex with an entire margin, creamy and with a pink colour.

Cells of strain BL1 showed great morphological variability, from coccoid to rod-shaped with some tendency to form branching rods. The cells were Gram-positive, partially acid-fast and non-motile. Other physiological characteristics of the bacterium were: catalase positive, oxidase negative and non-spore-forming.

Cell wall analysis (fatty acid and mycolic acid) of strain BL1 resulted in its classification within the CMN taxon, which includes the families Corynebacteriaceae, Mycobacteriaceae and Nocardiaceae. A comparison of the $16 \mathrm{~S}$ rRNA sequences showed strain BL1 to have $99 \cdot 2 \%$ and $99.8 \%$ similarity, respectively, to Rhodococcus erytbropolis and Nocardia calcarea. Due to recent reclassification, $N$. calcarea is now regarded as a synonym of R. erythropolis (Goodfellow, 1989; Rainey et al., 1995), strain BL1 was therefore identified as Rhodococcus erythropolis.

\section{Effect of $\mathrm{NaCl}$ on the growth of $\boldsymbol{R}$. erythropolis BL1}

R. erythropolis BL1 was capable of growth at salinities from 0 to $8 \% \mathrm{NaCl}$ (Fig. 1). Cell yields $\left(\Delta \mathrm{OD}_{600}\right.$ after $120 \mathrm{~h}$ incubation) were maximal between 1 and $3 \% \mathrm{NaCl}$. Incubations without added $\mathrm{NaCl}$ showed a cell yield 


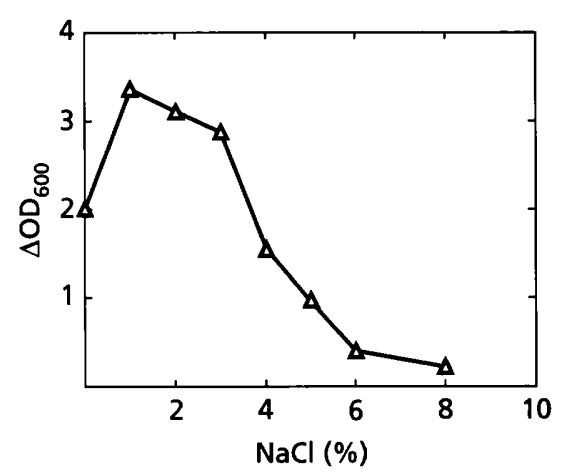

Fig. 1. Effect of salinity ( $\mathrm{NaCl}$ concentration) on the growth of $R$. erythropolis BL1. Growth was evaluated as $\Delta \mathrm{OD}_{600}$ after $120 \mathrm{~h}$ incubation.

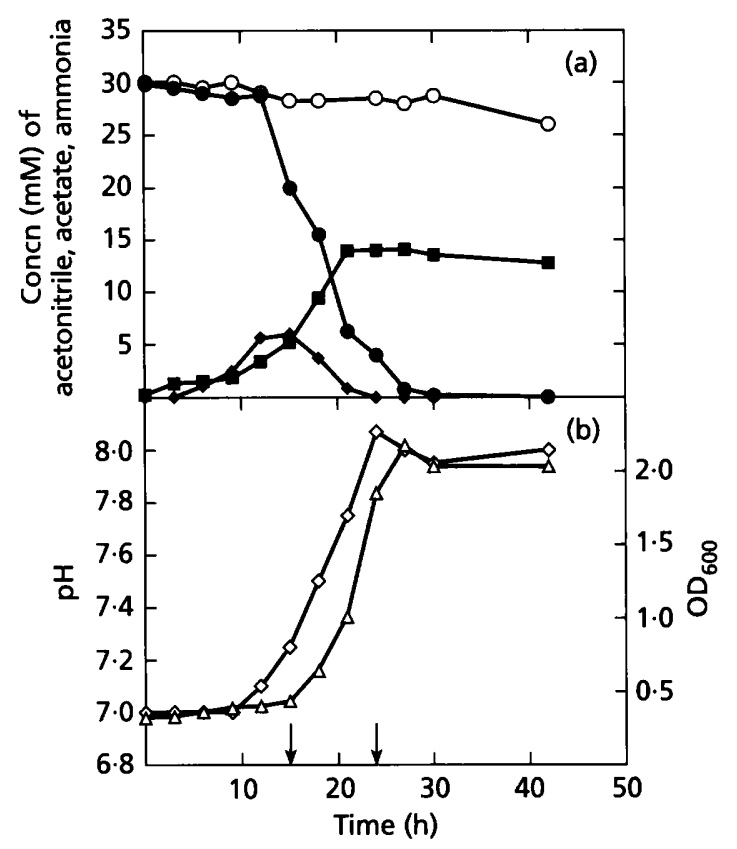

Fig. 2. Growth of $R$. erythropolis BL1 on DE medium containing a low concentration of acetonitrile $(30 \mathrm{mM})$. (a) $O$, Acetonitrile (sterile control); 0 , acetonitrile; $\diamond$, acetate; $\square$, ammonia. (b) $\triangle, \mathrm{OD}_{600} ; \diamond, \mathrm{pH} ;$ arrows indicate the start and end of the exponential growth phase.

corresponding to $80 \%$ of the maximum. At $\mathrm{NaCl}$ concentrations higher than $3 \%$, cell yields decreased rapidly, but slow growth occurred at $8 \% \mathrm{NaCl}$.

\section{Growth on and tolerance of acetonitrile}

Strain BL1 was able to grow in DE medium with $30 \mathrm{mM}$ acetonitrile as sole carbon and nitrogen source. A typical time course of cultivation is shown in Fig. 2. Upon inoculation, strain BL1 exhibited a lag phase of $12-15 \mathrm{~h}$, during which small amounts of acetonitrile were hydrolysed to ammonia and acetate, which accumulated in the

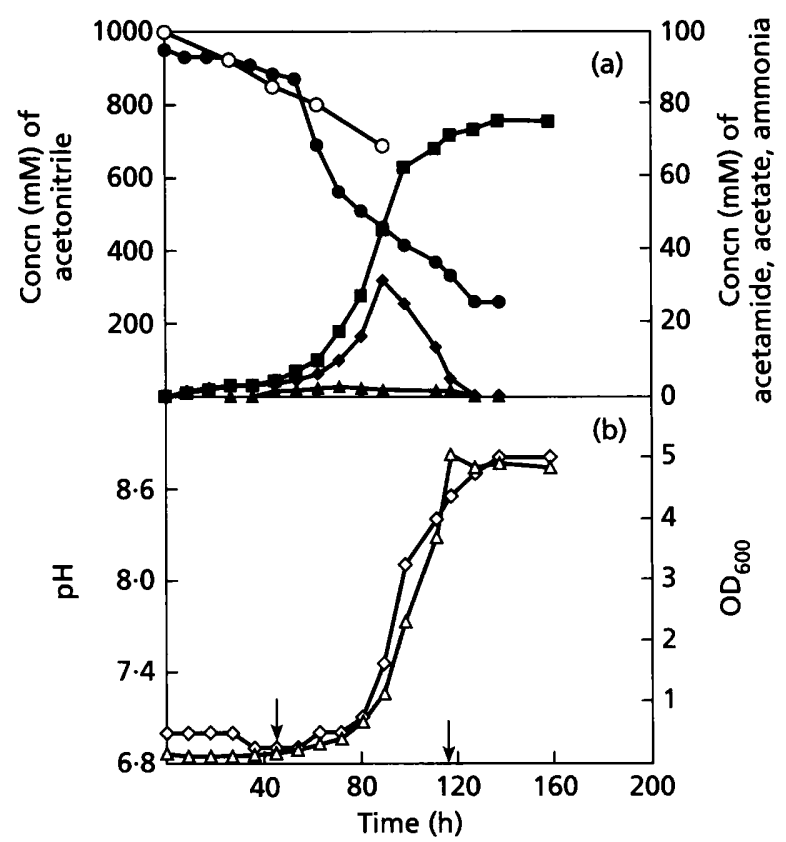

Fig. 3. Growth of $R$. erythropolis BL1 on DE medium containing a high concentration of acetonitrile (1 M). (a) $\bigcirc$, Acetonitrile (sterile control); $\boldsymbol{\theta}$, acetonitrile; $\boldsymbol{\Delta}$, acetamide; $\bullet$, acetate; $\boldsymbol{\square}$, ammonia. (b) $\triangle, \mathrm{OD}_{600} ; \diamond, \mathrm{pH}$; arrows indicate the start and end of the exponential growth phase.

medium. During exponential growth the acetonitrile concentration in the medium decreased rapidly and the ammonia concentration increased. Acetate produced from hydrolysis of acetonitrile served as carbon/energy source for growth and disappeared from the medium in midexponential growth $(\sim 25 \mathrm{~h})$. Ammonia accumulated to a final concentration of $13 \mathrm{mM}$ in the medium, causing the $\mathrm{pH}$ to increase from 7 to 8 .

No acetamide was detected in the culture medium of strain BL1 during the experiment shown in Fig. 2. Also, acetamide was never detected extracellularly in resting cell suspensions hydrolysing acetonitrile (data not shown). The detection limit for acetamide was $\sim 100 \mu \mathrm{M}$ by the GC method used. However, in rare instances, small amounts of amide were excreted by cells of strain BL1 (Fig. 3).

In order to elucidate the enzymic pathway of nitrile hydrolysis in strain BL1, inhibitor studies were performed using aldehydes as specific inhibitors of amidase activity (Amarant et al., 1989). Acetaldehyde $(2 \mathrm{mM})$ or formaldehyde $(1 \mathrm{mM})$, when added to aseptically washed cells incubated with $30 \mathrm{mM}$ acetonitrile, inhibited amidase activity of strain BL1, resulting in an accumulation of acetamide and a simultaneous cessation of ammonia production (data not shown). These inhibitor experiments strongly indicate the presence of a nitrile hydratase/ amidase enzyme system in R. erythropolis BL1. The reason why amide intermediates were not usually detected outside cells of strain BL1 during nitrile hydrolysis could have been the presence of a high level of amidase activity. 
This was confirmed in later experiments which showed that AHA was more than one order of magnitude higher than NHA (Table 1).

Cells of strain BL1 survived long exposures to high concentrations of acetonitrile. To investigate whether the strain was able to grow in the presence of high concentrations of acetonitrile, an experimental flask with $\mathrm{DE}$ medium containing $1 \mathrm{M}$ acetonitrile was inoculated with an exponential-phase culture from DE medium supplemented with $0.5 \%(\mathrm{v} / \mathrm{v})$ acetonitrile. A control flask containing sterile growth medium and $1 \mathrm{M}$ acetonitrile was run in parallel in order to quantify evaporation of acetonitrile during incubation (Fig. 3). Inoculation of strain BL1 into DE medium containing $1 \mathrm{M}$ acetonitrile resulted in a lag phase of about $50 \mathrm{~h}$, i.e. about threefold longer than with $30 \mathrm{mM}$ acetonitrile (Fig. 2). Little ammonia or acetate was excreted into the medium during the lag phase. The decline in acetonitrile concentration observed during this phase was mainly a result of evaporation (Fig. 3). Exponential growth started ( $50 \mathrm{~h}$ ) at an acetonitrile concentration of about $900 \mathrm{mM}$. Growth correlated with production of acetate and ammonia during the first half of the exponential growth period $(45-90 \mathrm{~h})$. Growth ceased at about $140 \mathrm{~h}$ as a result of $\mathrm{pH}$ inhibition. At this time ammonia production also ceased. Additional experiments showed that although strain BL1 tolerated exposure to $\mathrm{pH} 8.8$ for many hours it did not grow above this $\mathrm{pH}$ value (data not shown). Low concentrations of acetamide $(\sim 0.5 \mathrm{mM})$ were detected in the culture medium during part of this experiment (Fig. 3 ), in contrast to the previous growth experiment (Fig. 2). When strain BL1 entered the stationary phase $(\sim 125 \mathrm{~h})$ the culture medium contained $75 \mathrm{mM}$ ammonia and $260 \mathrm{mM}$ acetonitrile. A mass balance calculation showed that a total of about $340 \mathrm{mM}$ of acetonitrile was hydrolysed by strain BL1. This value was estimated from the data in Fig. 3 assuming a total evaporation loss of approx. $370 \mathrm{mM}$ acetonitrile (i.e. linear extrapolation between 0 and $130 \mathrm{~h}$ ). Assuming an average $\mathrm{C}: \mathrm{N}$ ratio of 5 for $R$. erythropolis BL1 cell synthesis ( $3 \cdot 0 \mathrm{mg}$ dry weight $\mathrm{ml}^{-1}$ ) would require the assimilation of a maximum of $20 \mathrm{mM}$ ammonia, thus leaving about $245 \mathrm{mM}$ ammonia (340 mM-20 mM-75 mM) unaccounted for. The low recovery of ammonia from the growth medium, which was also observed in the experiment of Fig. 2, is most likely due to ammonia stripping. Such a loss of ammonia was facilitated both by the continuous shaking employed and by the high $\mathrm{pH}(8 \cdot 8)$ of the medium towards the end of growth (the dissociation constant $\mathrm{pK}_{\mathrm{a}}$ for ammonia is 9.25). Additional experiments showed that significant amounts of ammonia disappeared from sterile experimental flasks containing ammonium chloride at $\mathrm{pH} 8 \cdot 8$.

The maximum growth rates measured at low (Fig. 2) and high (Fig. 3) acetonitrile concentrations were $0.15 \mathrm{~h}^{-1}$ and $0.07 \mathrm{~h}^{-1}$, respectively, which indicated that acetonitrile had an inhibitory effect on the growth of strain BL1. However, this strain exhibited an exceptionally high tolerance to acetonitrile. The growth rate and the length of the lag phase did not differ significantly at acetonitrile concentrations below $300 \mathrm{mM}$. At $500 \mathrm{mM}$ a much longer

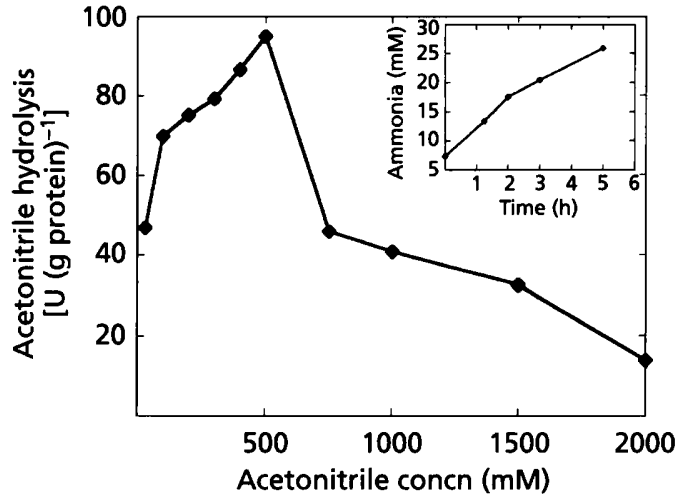

Fig. 4. Rate of hydrolysis of acetonitrile by intact cells of $R$. erythropolis BL1 as a function of acetonitrile concentration. Hydrolysis was measured as the initial rate of ammonia release over 60 min. Insert: time course of ammonia production at $2 \mathrm{M}$ acetonitrile.

lag phase was observed but the growth rate was identical $\left(0 \cdot 12 \mathrm{~h}^{-1}\right)$. Resting cells of R. erytbropolis BL1 exhibited a rather high saturation concentration for hydrolysis of acetonitrile. Fig. 4 shows a plot of the initial hydrolytic velocity by intact cells of BL1 versus acetonitrile concentration. Maximum hydrolytic activity was measured at $500 \mathrm{mM}$, with more than $15 \%$ activity remaining at $2 \mathrm{M}$. The high maximum of acetonitrile hydrolysis obtained (Fig. 4) may reflect hydrolysis being limited by diffusion of substrate into the cells below $500 \mathrm{mM}$. A slow efflux of the intracellularly produced ammonia at lower nitrile concentrations could be another explanation. The sharp decline in hydrolytic activity observed above $500 \mathrm{mM}$ acetonitrile is presumably due to substrate inhibition. It was, therefore, suprising that the hydrolytic activity was constant when washed cells were incubated for $6 \mathrm{~h}$ at $2 \mathrm{M}$ acetonitrile, which was the highest concentration tested (cf. Fig. 4, insert).

\section{Substrate specificity}

The nitrile hydratase/amidase system of R. erythropolis BL1 exhibited broad substrate specificity. Only eleven of the thirty-seven nitriles tested were not hydrated by washed cell suspensions of R. erythropolis BL1 (Table 1). However, hydrolysis of some nitrile compounds tested may have escaped detection as substrates for the nitrile hydratase, since activity was evaluated by measuring ammonia production. The hydrolytic system of $R$. erytbropolis BL1 had a clear preference for aliphatic saturated and unsaturated nitriles containing 2-4 carbon atoms, with propionitrile $\left(\mathrm{C}_{3}\right)$ being the most preferred substrate. The nitrile hydratase/amidase system of $R$. erythropolis BL1 also accepted side chains in the $\alpha-, \beta$ - and $\gamma$-positions (e.g. aminoacetonitrile, lactonitrile and 3hydroxypropionitrile), although these substrates were hydrated at lower rates than their unbranched counterparts. Cyanide $\left(\mathrm{CN}^{-} / \mathrm{HCN}\right)$ did not act as substrate (result not shown).

In contrast to Rbodococcus rbodochrous $\mathrm{J} 1$ and Nocardia 
Table 1. Hydrolysis rates of various nitriles and amides by acetonitrile precultivated cells of $R$. erythropolis BL1

Rates of acetonitrile and acetamide hydrolysis corresponding to $47 \mathrm{U}$ (g protein $)^{-1}$ and $1463 \mathrm{U}(\mathrm{g}$ protein $)^{-1}$, respectively, were taken as $100 \%$. -, No hydrolysis.

\begin{tabular}{|c|c|c|c|}
\hline Substrate & NHA (\%) & Substrate & NHA (\%) \\
\hline \multicolumn{4}{|c|}{ Nitriles } \\
\hline $\mathrm{C}_{2}$ & & $\mathrm{C}_{5}$ & \\
\hline Acetonitrile & 100 & 2-Methyl 2-butenenitrile & 126 \\
\hline Aminoacetonitrile & 51 & 3-Pentenenitrile & 70 \\
\hline Chloroacetonitrile & 47 & Valeronitrile & 47 \\
\hline Trichloroacetonitrile & 42 & Pivalinonitrile & 28 \\
\hline $\mathrm{C}_{3}$ & & $\mathrm{C}_{6}$ & \\
\hline Propionitrile & 2110 & Iminodipropionitrile & 49 \\
\hline Acrylonitrile & 688 & Adiponitrile & 46 \\
\hline Methacrylonitrile & 62 & Mucononitrile & 34 \\
\hline 3-Hydroxypropionitrile & 37 & & \\
\hline Lactonitrile & 37 & Aromatics & \\
\hline \multirow[t]{2}{*}{ Malonitrile } & - & Benzylpropionitrile & 88 \\
\hline & & Phenylacetonitrile & 31 \\
\hline $\mathrm{C}_{4}$ & & Cinnamonitrile & 22 \\
\hline Butyronitrile & 271 & Benzonitrile & - \\
\hline Allyl cyanide & 174 & Salicylonitrile & - \\
\hline Succinonitrile & 170 & Phthalonitrile & - \\
\hline 4-Chlorbuty ronitrile & 143 & 4-Cyanopyrine & - \\
\hline Isobutyronitrile & 121 & 3-Cyanopyrine & - \\
\hline Crotononitrile & 22 & Benzylcyanide & - \\
\hline Fumaronitrile & 6 & Benzylaminoacetonitrile & - \\
\hline \multirow[t]{2}{*}{ Iminodiacetonitrile } & - & Benzylmalonitrile & - \\
\hline & & Triphenylacetonitrile & - \\
\hline \multicolumn{4}{|c|}{ Amides } \\
\hline $\mathrm{C}_{2}$ & & $\mathrm{C}_{6}$ & \\
\hline Acetamide & 100 & Adipinamide & 9 \\
\hline \multirow[t]{2}{*}{ Chloroacetamide } & 25 & & \\
\hline & & Aromatics & \\
\hline $\mathrm{C}_{3}$ & & Phenylacrylamide & 7 \\
\hline Propionamide & 100 & Isonicotinamide & 6 \\
\hline Acrylamide & 76 & Salicylamide & 6 \\
\hline Cyanoacetamide & 13 & Nicotinamide & 3 \\
\hline N-Methylacetamide & 8 & Benzamide & 3 \\
\hline \multirow[t]{2}{*}{ Malonamide } & - & Diphenylacetamide & - \\
\hline & & Phthalamide & - \\
\hline \multicolumn{4}{|l|}{$\mathrm{C}_{4}$} \\
\hline Butyramide & 20 & & \\
\hline Succinamide & 9 & & \\
\hline
\end{tabular}

rhodocbrous LL100-21 (Mauger et al., 1988; Vaughan et al., 1989) cells of strain BL1 were inactive towards a number of aromatic and heterocyclic substrates having a $-\mathrm{CN}$ group attached directly or closely to the ring structure (e.g. benzonitrile, benzylcyanide, 3-cyanopyridine) whereas - $\mathrm{CN}$ groups attached to a $\mathrm{C}_{3}$ or $\mathrm{C}_{4}$ aliphatic side chain were accepted as substrates (e.g. benzylpropionitrile, cinnamonitrile). Notably, cultivation of R. erytbropolis BL1 in DE/acetonitrile medium containing benzo- nitrile or benzylcyanide did not result in the induction of enzyme activities against these compounds.

The amidase of R. erytbropolis BL1 exhibited highest activity towards short-chain aliphatic amides (i.e. acetamide and propionamide), the hydrolytic activity decreasing with increasing chain length or substitution (Table 1). Amide groups directly attached to the aromatic or heterocyclic ring (e.g. benzamide, nicotinamide) were 
Table 2. Ability of nitriles and amides to support growth of $R$. erythropolis BL1

Growth was monitored after $72 \mathrm{~h}$ incubation.,$+++ \mathrm{OD}_{600}>3 ;++, \mathrm{OD}_{600} 1-3 ;+, \mathrm{OD}_{600}<1$; - , no growth.

\begin{tabular}{|lclc|}
\hline Substrate & Growth & Substrate & Growth \\
\hline Acetonitrile & ++ & Acetamide & ++ \\
Propionitrile & +++ & 2-Chloroacetamide & + \\
Allyl cyanide & +++ & Propionamide & +++ \\
Butyronitrile & +++ & N-Methylacetamide & + \\
Isobuty ronitrile & + & Butyramide & +++ \\
Fumaronitrile & + & Benzamide & +++ \\
2-Methyl 2-butenenitrile & + & & \\
Benzonitrile & - & & \\
\hline
\end{tabular}

Table 3. Expression of NHA and AHA in R. erythropolis BL1 after growth in different types of defined media

Experimental flasks were inoculated with cells, which were either pregrown for several passages in (A) $\mathrm{DE} /$ glucose/ammonia medium or in (B) DE/acetonitrile medium. NHA and AHA are expressed as $U$ $(\mathrm{g} \text { protein })^{-1}$. NHA of inoculum cultures: $(\mathrm{A}): 0 \mathrm{U}$ (g protein $)^{-1},(\mathrm{~B}): 73 \mathrm{U}(\mathrm{g} \text { protein })^{-1}$. ND, Not done.

\begin{tabular}{|c|c|c|c|}
\hline Growth medium & NHA (24 h) & NHA (48 h) & AHA (24 h) \\
\hline \multicolumn{4}{|l|}{ (A) Non-induced } \\
\hline 1. Acetonitrile & 53 & & ND \\
\hline 2. Acetonitrile + glucose & 14 & & ND \\
\hline $\begin{array}{l}\text { 3. Acetonitrile }+ \text { glucose }+ \\
\text { ammonium }\end{array}$ & 3 & & ND \\
\hline 4. Acetamide + glucose & 0 & & 29 \\
\hline 5. Acetamide & 0 & & 78 \\
\hline 6. Glucose + ammonium & 0 & & 20 \\
\hline \multicolumn{4}{|l|}{ (B) Induced } \\
\hline 1. Acetonitrile & 73 & 39 & 1267 \\
\hline 2. Acetonitrile + glucose & 59 & 37 & ND \\
\hline $\begin{array}{l}\text { 3. Acetonitrile }+ \text { glucose }+ \\
\text { ammonium }\end{array}$ & 37 & 30 & ND \\
\hline 4. Acetamide + glucose & 14 & 14 & ND \\
\hline 5. Acetamide & 13 & 13 & 735 \\
\hline 6. Glucose + ammonium & 5 & 2 & 71 \\
\hline
\end{tabular}

hydrolysed, unlike the corresponding nitriles, which did not act as substrates for the nitrile hydratase (Table 1).

All the nitriles and amides hydrolysed by intact cells of $\mathrm{R}$. erythropolis BL1 were tested for their ability to serve as sole carbon and nitrogen sources for growth (Table 2). Simple aliphatic nitriles and amides supported growth, including unsaturated compounds such as allyl cyanide and 2methyl 2-butenenitrile. Strain BL1 grew well on benzamide, whereas benzonitrile could not support growth.

\section{Induction of NHA and AHA}

The induction patterns of NHA and AHA were investigated by inoculating non-induced cells (A) and induced cells (B) into different growth media (Table 3). The cells used as inocula were obtained from cultures pregrown for several passages in $\mathrm{DE} /$ glucose/ammonia medium and DE/acetonitrile medium, respectively. Noninduced cells regained $73 \%$ of the maximum $\mathrm{NHA}$ after $24 \mathrm{~h}$ growth in DE/acetonitrile medium (Table 3, A1). When cells were grown in $\mathrm{DE} /$ acetonitrile medium containing additional carbon and/or nitrogen sources, much lower induction levels were observed (Table 3, A2 and A3). Acetamide did not induce NHA in strain BL1, either as a nitrogen source or when serving as sole carbon and nitrogen source (Table 3, A4 and A5). No NHA was detected in the control culture growing without nitrile (Table 3, A6).

Induced cells were tested for their ability to retain their NHA and AHA after transfer to growth media containing 
different carbon/nitrogen sources (Table 3). Not surprisingly, the highest NHA [73 $\mathrm{U}$ (g cell protein) ${ }^{-1}$ ] was found in cells reinoculated into $\mathrm{DE} /$ acetonitrile medium (Table 3, B1). After the culture entered the stationary growth phase, the NHA decreased to $43 \%$ of the maximum level (Table 3, B1). The presence of additional carbon and nitrogen sources in the $\mathrm{DE} /$ acetonitrile medium significantly decreased expression of NHA in exponentially growing cells $(24 \mathrm{~h})$. The highest degree of repression was observed with cells grown in $\mathrm{DE} /$ acetonitrile medium supplemented with both glucose and ammonia (Table 3, B3). When induced cells were inoculated into a nitrile-free medium containing glucose and ammonia as sole carbon and nitrogen sources, the NHA decreased about $70 \%$ within $24 \mathrm{~h}$ (Table 3, B6). As seen from Table 3, acetamide did not induce NHA (Table 3, A5) although it somehow reduced repression of NHA in induced cells during subsequent growth in a nitrile-free medium (B4 and B5 vs B6). Cells lacking NHA always contained significant AHA even after many transfers in $\mathrm{DE} /$ glucose/ammonia medium (Table 3, A6). Even though the AHA of R. erytbropolis BL1 could be increased manyfold when cells were grown in the presence of acetamide (or acetonitrile), the results clearly demonstrate the constitutive nature of the AHA as opposed to the inducible nature of NHA.

\section{DISCUSSION}

Five physiologically different nitrile-hydrolysing bacteria were isolated from marine environments on the east and west coast of Denmark. None of these isolates originated from areas close to nitrile-processing industries, suggesting that nitrile-hydrolysing bacteria are common inhabitants of marine sediments.

The ecological significance of nitrile-hydrolysing enzymes in both Gram-positive and Gram-negative bacteria is unknown. Are these enzymes a reminiscence of early prokaryotic life, when organic cyano compounds were part of the biosphere (Oró \& Lazcano-Araujo, 1981; Ferris \& Hagan, 1984; Loomis, 1988) - or are they produced in response to as yet unidentified organonitriles present in the environment? A number of naturally occurring nitriles have been identified (Jallageas, 1981). Since most of these are not commercially available they have not been tested as possible substrates for nitrilehydrolysing enzymes. So far only a few biogenic nitriles (e.g. ricinine and mandelonitrile) have been reported to be hydrolysed by micro-organisms (Robinson \& Hook, 1964; Yamamoto et al., 1991). Inorganic cyanide $\left(\mathrm{HCN} / \mathrm{CN}^{-}\right)$is produced in vast amounts by natural synthesis (Vennesland et al., 1981; Knowles, 1985) and is, therefore, of widespread occurrence in nature. However, known nitrile hydratases and nitrilases are unable to hydrolyse cyanide. Another explanation for the presence of nitrile-hydrating enzymes in bacteria could be that these enzymes have an unspecific enzymic reaction.

R. erythropolis strain BL1, described in this study, was isolated from a marine sediment which is exposed to salinities ranging from $2 \cdot 4$ to $3.4 \%$. The strain grew in the presence of $0-8 \% \mathrm{NaCl}$ under laboratory conditions, with most rapid growth occurring with $1-3 \% \mathrm{NaCl}$ (Fig. 1). R. erythropolis BL1 thus showed a relatively wide salt tolerance when grown on acetonitrile as sole carbon and nitrogen source. Other nitrile-hydrolysing bacteria belonging to the CMN-taxon (e.g. Nocardia spp., Rhodococcus spp., Corynebacterium spp.) do not appear to have been isolated from marine environments. However, subsequent studies may show that some of these isolates are also able to grow well in both freshwater and marine media.

R. erytbropolis strain BL1 showed a much higher tolerance towards acetonitrile than reported previously for nitrilehydrolysing bacteria. It grew well in media containing $900 \mathrm{mM}$ acetonitrile (Fig. 3). Growth also occurred in DE medium containing $1.5 \mathrm{M}$ acetonitrile $(\sim 8 \%, \mathrm{v} / \mathrm{v})$, but with a long lag phase (unpublished results). In contrast, a Rhodococcus sp. studied by Miller \& Gray (1982) grew slowly at $2 \%(\mathrm{v} / \mathrm{v})$ but was virtually inhibited at $3 \%$. A nitrile-hydrolysing strain of Corynebacterium nitrilopbilus investigated by Mimura et al. (1969) tolerated up to $5 \%$ $(\mathrm{v} / \mathrm{v})$. It is possible that the high tolerance of R. erythropolis BL1 was a result of physiological adaptation occurring while the strain was routinly maintained on a medium containing $0.5 \%$ acetonitrile as sole carbon and nitrogen source.

The rate of acetonitrile hydrolysis (NHA) by resting cells of R. erytbropolis BL1 also exhibited a high substrate tolerance, with maximum activity at $500 \mathrm{mM}$ and with similar hydrolysis rates at $30 \mathrm{mM}$ and $2 \mathrm{M}$. The NHA (and AHA) of strain BL1 were found to be 'cell-bound' - most likely in the cytoplasm (results not shown) which also seems to be the case for nitrile hydratase/amidase systems described in other bacteria (Miller \& Knowles, 1984; Linton \& Knowles, 1986). It would be interesting to know the concentration of acetonitrile present within the cells during nitrile hydrolysis at high external concentrations which are likely to be inhibitory to many intracellular enzymes. However, such data are not available to our knowledge.

Many studies on substrate specificity have been conducted with intact whole cells (e.g. DiGeronimo \& Antoine, 1976; Arnaud et al., 1980; Miller \& Gray, 1982; Collins \& Knowles, 1983; Ingvorsen et al., 1988; Amarant et al., 1989), which have clearly demonstrated that a large number of structurally different nitriles and amides can penetrate Gram-positive cells. Experiments performed with Corynebacterium nitrilophilus by Amarant's group (Amarant et al., 1989) revealed no differences in the kinetic behaviour between whole cells, cell extracts and purified nitrile hydratase when testing small nitrile molecules. These data, therefore, suggest that the reaction is not limited by diffusion (Amarant $e t$ al., 1989). Knowledge of the mechanism(s) of nitrile uptake by bacteria is, however, extremely limited (Miller \& Knowles, 1984; Vaughan $e t$ al., 1988; Amarant et al., 1989). At present it cannot, therefore, be excluded that the nitrile hydratase/amidase enzyme system in the cytoplasm is exposed to substrate concentrations significantly lower than those of the 
surrounding medium. If, however, Gram-positive cells are readily permeable to nitriles, high hydratase and amidase activities could be a means of maintaining low intracellular concentrations of toxic substrates and products.

Resting cells of R. erytbropolis strain BL1 pregrown in acetonitrile medium were completely inactive towards benzonitrile and benzylcyanide (Table 1). Micro-organisms closely related to R. erytbropolis BL1 (e.g. $N$. rhodochrous NCIB 11216, Brevibacterium R312, N. rbodochrous LL100-21, R. erytbropolis CH5 and C. nitrilophilus) have been reported to hydrolyse a number of aromatic nitriles such as benzonitrile, benzyl cyanide and cyanopyridines either by means of a broad-spectrum nitrile hydratase or a nitrilase specific for aromatic nitriles (Harper, 1977; Arnaud et al., 1977; Collins \& Knowles, 1983; Ingvorsen et al., 1988; Amarant et al., 1989). A nitrile hydratase also lacking activity towards aromatic nitriles was reported in N. rhodocbrous LL100-21. This strain was, however, able to induce a separate nitrilase enzyme for conversion of benzonitrile directly to benzoate after cultivation in a benzonitrile-containing medium (Collins \& Knowles, 1983). Growth of R. erytbropolis BL1 in $\mathrm{DE} /$ acetonitrile medium supplemented with benzonitrile or benzylcyanide did not result in the induction of enzyme activities towards these compounds.

The data in Table 3 show that expression of nitrile hydratase and amidase activities in strain BL1 were not closely coupled, which probably means that the structural genes coding for NHA and AHA are located on different operons. In R. erythropolis BL1, NHA was not induced by acetamide, although it appeared to reduce repression of NHA (Table 3, B4 and 5). These results are clearly at variance with these obtained with Rhodococcus sp. and Nocardia rhodochrous LL100-21, where acetamide was found to be a powerful inducer of the nitrile hydratases (Miller \& Gray, 1982; Collins \& Knowles, 1983). It was suggested that the structural genes for NHA and AHA in these two micro-organisms were located on the same operon and expressed concurrently, e.g. after induction by acetamide (Linton \& Knowles, 1986; Mayaux et al., 1990; Ikehata et al., 1989). Later studies did indeed show nitrile hydratases and amidases to be present on the same operon (Kobayashi et al., 1992, 1993).

The 'cell-bound' nitrile hydratase/amidase system of $R$. erythropolis BL1 was extremely tolerant to high concentrations of acetonitrile (Figs 3 and 4). Due to this property and its broad substrate specificity the nitrile hydratase/ amidase enzyme system of strain BL1 may be of potential use for synthesis or detoxification processes.

\section{REFERENCES}

Amarant, T., Vered, Y. \& Bohak, Z. (1989). Substrates and inhibitors of the nitrile hydratase and amidase of Corynebacterium nitrilophilus. Biotechnol Appl Biochem 11, 49-59.

Arnaud, A., Galzy, P. \& Jallageas, J. C. (1977). Etude de l'acétonitrilase d'une souche de Brevibacterium. Agric Biol Chem 44, $2251-2252$.
Arnaud, A., Galzy, P. \& Jallageas, J. C. (1980). Production d'acidesamidés stéréospécifiques par hydrolyse biologique $\mathrm{d}^{\prime}$-aminonitriles racémiques. Bull Soc Cbim Fr 2, 87-90.

Asano, A., Fujishiro, K., Tani, Y. \& Yamada, H. (1982). Aliphatic nitrile hydratase from Arthrobacter sp. J-1. Purification and characterization. Agric Biol Chem 46, 1165-1174.

Bower, C. E. \& Holm-Hansen, T. (1980). A salicylate-hypochlorite method for determining ammonia in seawater. Can J Fish Aquat $S_{c i}$ 37, 794-798.

Chapatwala, K. D., Babu, G. R. V., Dudly, C., Williams, R. \& Aremu, K. (1993). Degradative capability of Pseudomonas putida on acetonitrile. Appl Biochem Biotechnol 39/40, 655-666.

Collins, P. A. \& Knowles, C. J. (1983). The utilization of nitriles and amides by Nocardia rbodochrous. J Gen Microbiol 129, 711-718.

DiGeronimo, M. J. \& Antoine, A. D. (1976). Metabolism of acetonitrile and propionitrile by Nocardia rhodochrous LL100-21. Appl Environ Microbiol 31, 900-906.

Doetsch, R. N., Smibert, R. M. \& Krieg, N. R. (1981). In Manual of Methods for General Bacteriology, pp. 21-34, 409-444. Edited by P. Gerhardt, R. G. E. Murray, R. N. Castilow, E. W. Nester, W. A. Wood, N. R. Krieg \& G. B. Phillips. Washington, DC: American Society for Microbiology.

Ferris, J. P. \& Hagan, W. J. (1984). HCN and chemical evolution: the possible role of cyano compounds in prebiotic synthesis. Tetrabedron 40, 1093-1120.

Finnegan, I., Toerien, S., Smit, F. \& Raubenheimer, H. G. (1992). Commercial application of microbial enzymes with nitrile degrading activity. $S$ Afr J Sci 88, 188-189.

Goa, J. (1953). A micro biuret method for protein determination. Determination of total protein in cerebrospinal fluid. Scand J Clin Lab Invest 5, 218-222.

Goodfellow, M. (1989). Genus Rhodococcus Zopf 1891, 28 $8^{\mathrm{AL}}$. In Bergey's Manual of Systematic Bacteriology vol. 4, pp. 2362-2371. Edited by S. T. Williams, M. E. Sharpe \& J. G. Holt. Baltimore: Williams \& Wilkins.

Goodfellow, M. \& Lechevalier, M. P. (1989). Genus Nocardia Trevisian 1889, $9^{\text {AL }}$. In Bergey's Manual of Systematic Bacteriology vol. 4, pp. 2350-2361. Edited by S. T. Williams, M. E. Sharpe \& J. G. Holt. Baltimore: Williams \& Wilkins.

Harper, B. D. (1977). Microbial metabolism of aromatic nitriles. Enzymology of C-N cleavage by Nocardia sp. (rhodochrous group). Biochem J 165, 309-319.

Ikehata, O., Nishiyama, M., Horinouchi, S. \& Beppu, T. (1989). Primary structure of nitrile hydratase deduced from the nucleotide sequence of a Rhodococcus species and its expression in Escherichia coli. Eur J Biochem 181, 563-570.

Ingvorsen, K., Yde, B., Godtfredsen, S. E. \& Tsuchiya, R. (1988). Microbial hydrolysis of organic nitriles and amides. In Cyanide Compounds in Biology (Ciba Foundation Symposium 140), pp. 16-31. Edited by D. Evered \& S. Harnett. Chichester: John Wiley.

Ingvorsen, K., Højer-Pedersen, B. \& Godtfredsen, S. E. (1991). Novel cyanide-hydrolyzing enzyme from Alcaligenes xylosoxidans subsp. denitrificans. Appl Environ Microbiol 57, 1783-1789.

Jallegeas, J. C., Arnaud, A. \& Galzy, P. (1980). Bioconversion of nitriles and their applications. In Advances in Biochemical Engineering vol. 14, pp. 1-32. Edited by A. Fiechter. Berlin \& New York: Springer-Verlag.

Knowles, C. J. (1985). Microbial degradation of cyanide. World Biotech Rep 537-542.

Knowles, C. J. \& Wyatt, J. W. (1992). The degradation of cyanide and nitriles. In Microbial Control of Pollution (Society for General 
Microbiology Symposium 48), pp. 113-128. Edited by J. C. Fry, G. M. Gadd, R. A. Herbert, C. W. Jones \& I. A. Watson-Craik. Cambridge: Cambridge University Press.

Kobayashi, M., Nagasawa, T. \& Yamada, H. (1992). Enzymatic synthesis of acrylamide: a success story not yet over. Trends Biotechnol 10, 402-408.

Kobayashi, M., Komeda, H., Nagasawa, T., Nishiyama, M., Horinouchi, S., Beppu, T., Yamada, H. \& Shimizu, S. (1993). Amidase coupled with low-molecular-mass nitrile hydratase from Rhodococcus rbodocbrous J1. Eur J Biochem 217, 327-336.

Linton, E. A. \& Knowles, C. J. (1986). Utilization of aliphatic amides and nitriles by Nocardia rbodochrous LL100-21. J Gen Microbiol 132, 1493-1501.

Loomis, W. F. (1988). The prebiological environment. In Four Billion Years, part 1, pp. 4-12. Sunderland, MA: Sinauer Associates.

Mauger, J., Nagasawa, T. \& Yamada, H. (1988). Nitrile hydratasecatalyzed production of isonicotinamide, picolinamide and pyrazinamide from 4-cyanopyridine, 2-cyanopyridine and cyanopyrazine in Rhodococcus rbodocbrous J1. J Biotechnol 8, 87-96.

Mayaux, J.-F., Cerbelaud, E., Soubrier, F., Faucher, D. \& Pétré, D. (1990). Purification, cloning, and primary structure of an enantiomer-selective amidase from Brevibacterium sp. strain R312: structural evidence for genetic coupling with nitrile hydratase. $J$ Bacteriol 172, 6764-6704.

Miller, J. M. \& Gray, D. O. (1982). The utilization of nitriles and amides by a Rhodococcus species. J Gen Microbiol 128, 1803-1809.

Miller, J. M. \& Knowles, C. J. (1984). The cellular location of nitrilase and amidase of Brevibacterium R312. FEMS Microbiol Lett 21, 147-151.

Mimura, A., Kawano, T. \& Yamaga, K. (1969). Application of microorganisms to petrochemical industry. I. Assimilation of nitrile compounds by microorganisms. J Ferment Technol 47, 631-638.

Nagasawa, T. \& Yamada, H. (1989). Microbial transformation of nitriles. Trends Biotechnol 7, 153-158.
Nawaz, M. S., Heinze, T. M. \& Cerniglia, C. A. (1992). Metabolism of benzonitrile and butyronitrile by Klebsiella pneumoniae. Appl Environ Microbiol 58, 27-31.

Oró, J. \& Lazcano-Araujo, A. (1981). The role of HCN and its derivatives in prebiotic evolution. In Cyanide in Biology, pp. 517-541. Edited by B. Vennesland, E. E. Conn, C. J. Knowles, J. Westley \& F. Wissing. London: Academic Press.

Rainey, F. A., Burghardt, J., Kroppenstedt, R. M., Klatte, S. \& Stackebrandt, E. (1995). Phylogenetic analysis of the genera Rhodococcus and Nocardia and evidence for the evolutionary origin of the genus Nocardia from within the radiation of $R$ bodococcus species. Microbiology 141, 523-528.

Robinson, W. G. \& Hook, R. H. (1964). Ricinine nitrilase. $J$ Biol Chem 239, 4257-4262.

Vaughan, P. A., Cheetham, P. S. J. \& Knowles, C. J. (1988). The utilization of pyridine carbonitriles and carboxamides by Nocardia rbodocbrous LL100-21. J Gen Microbiol 134, 1099-1107.

Vaughan, P. A., Knowles, C. J. \& Cheetham, P. S. J. (1989). Conversion of 3-cyanopyridine to nicotinic acid by Nocardia rbodocbrous LL100-21. Enzyme Microb Technol 11, 815-823.

Vennesland, B., Pistorius, K. \& Gewitz, H.-S. (1981). HCN production by microalgae. In Cyanide in Biology, pp. 349-361. Edited by B. Vennesland, E. E. Conn, C. J. Knowles, J. Westley \& F. Wissing. London: Academic Press.

Wyatt, J. M. \& Linton, E. A. (1988). The industrial potential of microbial nitrile biochemistry. In Cyanide Compounds in Biology (Ciba Foundation Symposium 140), pp. 32-48. Edited by D. Evered \& S. Harnett. Chichester: John Wiley.

Yamamoto, K., Oishi, K., Fujimatsu, I. \& Komatsu, K.-I. (1991). Production of R-(-)-mandelic acid from mandelonitrile by Alcaligenes faecalis ATCC 8750. Appl Environ Microbiol 57, 3028-3032.

Received 6 April 1995; revised 1 September 1995; accepted 19 September 1995. 